THE INTERNATIONAL

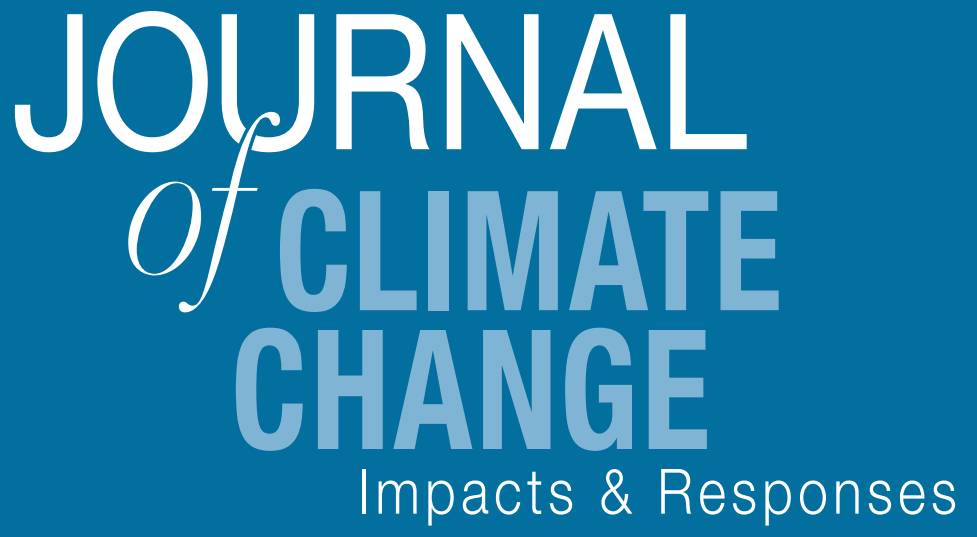

Volume 2

Climate Change and Classroom: The Power of Weather to Interfere with Global Education

Olav Titus Muurlink and Cristina Poyatos Matas 
THE INTERNATIONAL JOURNAL OF CLIMATE CHANGE: IMPACTS AND RESPONSES

http://www.Climate-Journal.com

First published in 2010 in Champaign, Illinois, USA by Common Ground Publishing LLC www.CommonGroundPublishing.com.

C 2010 (individual papers), the author(s)

(C) 2010 (selection and editorial matter) Common Ground

Authors are responsible for the accuracy of citations, quotations, diagrams, tables and maps.

All rights reserved. Apart from fair use for the purposes of study, research, criticism or review as permitted under the Copyright Act (Australia), no part of this work may be reproduced without written permission from the publisher. For permissions and other inquiries, please contact

<cg-support@ commongroundpublishing.com>.

ISSN: $1835-7156$

Publisher Site: http://www.Climate-Journal.com

THE INTERNATIONAL JOURNAL OF CLIMATE CHANGE: IMPACTS AND

RESPONSES is peer-reviewed, supported by rigorous processes of criterion-referenced article ranking and qualitative commentary, ensuring that only intellectual work of the greatest substance and highest significance is published.

Typeset in Common Ground Markup Language using CGCreator multichannel typesetting system

http://www.commongroundpublishing.com/software/ 


\title{
Climate Change and Classroom: The Power of Weather to Interfere with Global Education
}

\author{
Olav Titus Muurlink, Griffith University, Qld, Australia \\ Cristina Poyatos Matas, Griffith University, Qld, Australia
}

\begin{abstract}
Climate change research has focused on the economic and health impacts of changes in temperature and precipitation. This paper represents an early formal review of the likely impacts of climate change on education and the educability of primary and secondary children. Climate is likely to impact on education through three principle pathways: through the impact on the economy and health, and directly, either by impeding students' ability to attend school, or through biometeorological or psychometeorological impacts on either children or teachers. This study reviews existing evidence suggesting that climate will also impact on education through a number of other less immediately obvious pathways. Finally, the paper suggests a model that predicts that climate change will differentially impact on poor, rural, female students and teachers.
\end{abstract}

Keywords: Climate, Weather, Education, School Attendance, Developing World, Child Labor

\section{Introduction: New Threats to School Attendance and Performance}

LIMATE CHANGE COMMENTATORS have acknowledged a role for global changes in temperature, sea levels, and precipitation on everything from beach-front property prices (e.g. Werner, Hennecke, Greve, Cowell \& Thom, 2004) to cardiovascular mortality (Patz, Campbell-Lendrum, Holloway \& Foley, 2005), but the impact of climate change on our ability to educate our young has been curiously absent from the literature.

This review gathers evidence to support the contention that climate change, posited to increase the frequency and amplitude of extreme weather events, as well as shift baseline temperatures, humidity and precipitation, will have a significant impact on the delivery of education to, and the educability of, children. This review fills a significant gap in the literature by establishing a framework for the impact of climate change on education, a framework that has been largely absent in the literature to date. It establishes the impact of this relationship, in the developed and developing world, through the systematic review of different bodies of the literature available from the fields of economics, health and education.

Today, education planners in the developed world work with tools such as school room air-conditioning, car-pooling and bus routes to ensure children are delivered to school, regardless of the weather. Such has been the success of these measures, that weather barely affects school attendance patterns today. Even in the wake of a serious flood in the central Shenandoah Valley of western Virginia in the 1980s, researchers were unable to discern a significant increase in school absenteeism in the seven months following the flood, compared to attendance records for the previous relatively dry decade (Echterling, 1989).

The International Journal of Climate Change: Impacts and Responses Volume 2, 2010, http://www.Climate-Journal.com, ISSN 1835-7156 (C) Common Ground, Olav Titus Muurlink, Cristina Poyatos Matas, All Rights Reserved, Permissions: cg-support@commongroundpublishing.com 
A century ago, there was no such reluctance on the part of writers in the field of education to ascribe a role to the weather in determining important outcomes such as school attendance, truancy and absenteeism. In 19th century England, for example, in some parts of the Fen country in North Riding, children living more than two miles from school were exempted from compulsory schooling, such was the impediment offered by muddy cart tracks and winter snow. Wealthier children could choose not to opt out, in all but the most inclement weather, being able to cover the distance literally comfortably, on horseback, or in a horsedrawn conveyance (Ellis, 1973).

Absenteeism may seem like a blunt instrument in determining the blow weather can deliver to education, and this paper will show that it is by no means the only means with which weather affects education. It is nevertheless a highly significant one. Absenteeism significantly predicts education outcomes, acting on outcomes primarily by disrupting learning. Absenteeism predicts premature school dropout (Freudenberg, Feldman \& Clark, 1980; Fowler, Davenport \& Garg, 1992), and poor school performance (Moonie, Sterling, Figgs \& Castro, 2006), even after as brief an absence as two days (Breuner, Smith \& Womack, 2004). Significantly, absenteeism is often used in the literature as a proxy for child health, as well as an early alarm system of more serious medical problems (Currie, Hanushek, Kahn, Neidell \& Rivkin, 2009).

In the following brief review of what is an extremely large literature on the variables that impact on education performance, repeated reference will be made to differences between developing and developed economies. In considering this difference, it is necessary to make a distinction between absenteeism, defined as period of non-attendance (Strickland, 1998) from truancy (defined as deviant absence from school without parental knowledge and consent (Bell, Rosen \& Dynlacht, 1994; Lee \& Miltenberger, 1996). Truancy is increasing rapidly in the western world. For example, in the US, figures suggest that truancy rose by $85 \%$ within the ten years from 1989 (Baker, Sigmon \& Nugent, 2001). Absenteeism, on the other hand, accounts for the lion's share of school absence in the developing world.

Even a cursory glance at the education literature will confirm that at least in developing countries, the weather accounts for a significant proportion of the variance in attendance, either by impacting on the wealth or the health of communities. However, this paper argues that climate, and by extension climate change, has a significant potential impact on the education and educability of children, through a number of different causal pathways. Firstly, climate has biological and psychological sequelae. Secondly, climate, through its economic consequences, impedes parents' ability and willingness to allow their children to attend school. And finally, in the manner hinted at in the earlier example of the children heading to school through the snow on horseback, climate always has had a direct ability to stop children from gaining the benefits of education.

\section{Biometeorology and Psychometeorology}

The field of biometeorology explores the interaction between the weather and the biosphere. Side by side with this science is an emerging field that might well best be referred to as psychometeorology. The weather has proven effects on suicidal tendencies (Sullman, 1976), depression (Partonen \& Lönnqvist, 1998), and even willingness to help others (Cunningham, 1979). In a rare demonstration of psychometeorology in the classroom Essa, Hilton and Murray (1990) observed 67 pre-schoolers and found that during, or just after, a period of 
stable weather, children were more likely to interact with class materials. However, during or just after unstable weather, children showed a tendency to interact more with their peers and adults. The differences were reliable and highly significant, and were more pronounced for girls. Climates ability to act directly on cognition and mood is at least partially mediated by its effects on neurotransmitters, notably serotonin and melatonin (Winkler, Pjrek, Iwaki \& Kasper, 2006; McColl \& Veitch, 2001; Srinivasan, Smits, Spence, Lowe, Kayumov, Pandi-Perumal \& Cardinali, 2006), both of which are regulated by exposure to sunlight.

Moving on to the of field biometeorology, the impact of weather is so pervasive, that this paper can only provide a brief overview of aspects of the literature that underline the importance of climate to education and the importance of health to education. In this regard, it is worth noting that the US National Center for Health Statistics found absenteeism to be more pronounced amongst those with poor or merely fair health compared with those in good or excellent health $(27.2 \%$ and $4.4 \%$ respectively (Kearney \& Bensaheb, 2006).

Amongst the obvious candidates for keeping children from school, both in developed and developing countries are respiratory diseases such as the common cold and asthma. A study of 350,000 absentee Texan youngsters (Boyer, Bixler, Gordon, Heck \& Lee, 1939) showed the power of the common cold and its more dangerous cousin, influenza, has been shown to be responsive to climate variables (Lowen, Mubareka, Steel \& Palese, 2007). Asthma has been directly linked to school absenteeism (Moonie et. al., 2006), and the weather (e.g. Hobday \& Stewar, 1973), with the weather also mediating levels of pollen count and presence of fungi spores. The prevalence of respiratory disease is also partially determined by the level of particulates in the air, which in turn is believed to be one of the determinants of climate change (Swart, Amann, Raes \& Tuinstra, 2004). Air pollution has also been directly linked with absenteeism (Park, Lee, Ha, Lee, Kim \& Hong, 2002; Ransom \& Pope, 1992).

In the developing world, malaria remains a highly significant health problem, directly responsive to the weather, and directly responsible for school attendance and performance (Clark, Brooker, Njagi, Jau, Estambale, Muchiri \& Magnussen, 2004; Fernando, De Silva, Carter, Mendis \& Wickremasinghe, 2006). In fact, Fernando et al. (2006) were able to link lower language scores to the incidence of malaria attacks and higher scores to the prevalence of anti-malarial drugs.

While malaria and respiratory diseases together account for millions of absentee school days every year, the weather also has some more unusual health correlates. Working with self and parent-report data, Roth-Isigkeit, Thyen, Stove, Schwarzenberger and Schmucker (2005) found that weather was a significant predictor of pain in children, particularly amongst girls, while Masterson, Borton, and O'Brien (1993) were able to link the prevalence of fractures with meteorological data.

\section{Weather-mediated Economic Impacts on Children's Ability to Study}

The socioeconomic status (SES) of a family predicts school attendance both in the developed (Kearney \& Bensaheb, 2006), and the developing world (Cain, 1977). One of the key intermediaries of this relationship is the degree to which children are involved in the workforce. Children with lower SES working parents are frequently involved in baby-sitting of siblings (Bell et al., 1996) to maximise family income, but in the developing world, call on children to work is much more widespread. With climate change, the demand for child labour appears likely to increase, particularly since child labour appears to be used as a buffer for short-run 
economic shocks (Duryea, 1998) of the nature that follow extreme weather events, or rainfall surpluses or deficits. An effect on attendance has been noted in bad weather, for example, Hurricane Mitch, in Nicaragua (Baez \& Santos, 2007), and a corresponding lift in attendance has been noted for good weather in Ghana and Pakistan (Bhalotra \& Heady, 2000).

These two studies proved that child labour force participation need not mean absenteeism to the same degree, with work and school occupying a child's waking hours. The child labour issue additionally highlights the role of economic factors in buffering the impact of the weather. For example, Jacoby and Skoufias (1997) observed significant impacts on school attendance in poorer Indian communities, while weather had a relatively muted impact in wealthier villages. This difference has also been observed in the developed world (Stokes \& Walton, 1999).

The diversion of school children from school to the workplace has measurable consequences in terms of academic performance. Affected children may remain enrolled at school, but their attendance at school and attention to schoolwork is threatened (Orazem \& Gunnarsson, 2003), with consequences on the quality of achievements (Singh, 1998), and grade progression (Sedlacek, Duryea, Ilahi \& Sasaki, 2003; Rosati \& Rossi, 2001). Labour during school years in facts predicts an early exit from school (Psacharopoulos, 1997); and greater poverty as an adult (Ilahi, Orazem \& Sedlack, 2000). Anything that affects the wealth of a community affects the time and attention the children in that community can afford to give education, which will in turn affect the long-term economic prosperity of their community.

\section{Direct Impact of Weather on Education}

With the advent of elevated motorways and bridges, as well as motorised vehicles capable of traversing difficult road conditions, the impact of the weather on children to reach school has been reduced. In tropical and sub-tropical regions of Australia, governments have implemented measures such as Queensland's "Cooler Schools" program, to ensure children work in climate-controlled environments (Queensland Government, 2006). The results still allow some weather-attendance interaction.

Ransom and Pope (1992) observed an association between snowfall and absenteeism, a relationship no doubt partially mediated by access to all-weather roads, and partially through health. Ozone is associated with temperature, and it has been associated with depression of lung and airway function (Lippmann, 1989).

The situation in developing countries is similar to conditions experienced in the developed world a century ago. All-weather, or even dry weather routes to school (as opposed to no roads) predict school attendance (Afridi, 2007; Amssalu, 2003), and distance to school is closely related to attendance (Masouleh, 2006). As noted in the previous section, gender seems to play a role, with evidence from Bangladesh suggesting girls are more likely to be vulnerable to distance/attendance interference (Bhalotra \& Heady, 2000).

Apart from its impact in terms of attendance, weather has a direct role in educational outcomes. There is little existing research in support of the contention, made by Amssalu in 2003, that high temperatures may directly interfere with teachers' ability to teach, and children's ability to learn. However, evidence from psychology suggests a significant role, for example, Anderson, Dueser and De Neve (1995) demonstrated that temperature may directly increase sub-conscious levels of arousal, which can directly impact on an individual's ability 
to process information efficiently (e.g. Berlyne, 1960), as well as increasing hostile affects and cognitions, as noted earlier. Global warming may well, then, have a direct effect on classroom dynamics as well as student receptivity to learning.

\section{Conclusion}

Education is in many senses a special case in considering the future impact of climate change. Because of its pivotal role in determining the wealth of nations, the impact of climate change on education could have a compounded impact on human society.

The link between climate and economic outcomes is well-established; the same applies to human health. Climate has the ability to directly impact on education, particularly in poorer nations, even without directly and immediately impacting on the wealth of those nations. In some developing countries annual inundation of low-lying land is part of an annual cycle that determines soil fertility and crop viability. Nevertheless, the inundation poses a problem to educators and their charges. In low-lying countries such as Bangladesh, there is a real problem for small children, in particular, to safely reach their school desks during the annual monsoon. The floods pose a problem even to those very few children who have bicycles, and female teachers trying to wade to work and keep their saris dry. Education is not unique amongst the fields of human endeavour, but its importance on the one hand, and vulnerability on the other, to climate change, suggests it deserves a prominent role in the debate over the impact of climate change-a prominence hitherto absent.

This paper suggests that changes in climate will not equitably impact on all sectors of human society. Firstly, it is clear that developing countries will be particularly vulnerable, lacking the infrastructure to mitigate the climate impacts on human health and infrastructure that are prerequisite to an orderly education system. Economic impacts will differentially draw children into the workforce to a greater degree in developing countries. The impact on rural districts will clearly be greater, not simply because these districts tend to be economically weaker and host poorer infrastructure. Rural schools, by their nature, are further removed from their students compared to their urban cousins. Consequently, the student population will more frequently miss school as a result of extreme weather events.

Finally, there is good evidence that climate change impacts on education will differentially disadvantage girls and women from developing countries. On a biological level, there is evidence that females react differently to climatic changes. On a socio-cultural level, evidence suggests women and girls are in the front line of buffering their communities against the economic consequences of weather shocks.

Schools in developing countries often play a role in their community beyond purely education. As Ana, an Argentinean primary school teacher from a remote island school, explains:

The children eat at the school, and the school provides the children with clothing, tools and medicines etc. However we have to adapt to the inclement weather, because we navigate between seven and eight hours a day on the River Paraná in order to go back and forth to school, and we have to go through fog, wind and rain. During the winter, the cold makes it impossible for the children to reach the launch in the first place, so that attendance is low. As teachers we try to develop strategies that will help these children to reach the levels of competencies established by the government. (Educar, 2010) 
The school is situated in a context very much controlled by the weather, hot and cold, wet and dry. If we are ever to achieve UNESCO's "Education for All" goals (UNESCO, 2010), then the impact of climate change in education needs to be taken into account. This paper represents an early foray into a field that is likely to rapidly develop as climate change unfolds. It predicts that climate change will first impact on education in the remote, rural and disadvantaged margins of global society. However the impact of significant changes in global temperature, sea levels, precipitation and humidity on education, even in the developed world, will be significant enough to warrant immediate attention.

\section{References}

Afridi, F. (2007) Child Welfare Programs and Child Nutrition: Evidence from a Mandated SchoolMeal Program in India. Syracuse University, mimeo.

Amssalu, T. (2003). Socio Economic Factors Affecting Female Child Labour and School Attendance: The Case of Menge and Komosha Woreda of Benishangul Gumuz National Regional state. Regional and local Development Studies. PhD Thesis, Addis Ababa University.

Anderson, J. (1926). The attendance of nursery school children. School and Society, 24, 182-184.

Anderson, C., Deuser, W., \& DeNeve, K. (1995). Hot temperatures, hostile affect, hostile cognition, and arousal: Tests of a general model of affective aggression. Personality and Social PsychologyBulletin, 21, 434-448.

Baez J., \& Santos I. (2007). Children's Vulnerability to Weather Shocks: A Natural Disaster as a Natural Experiment. Retrieved March $15^{\text {th }} 2010$ from http://siteresources.worldbank.org/INTMIGDEV/Resources/2838212-1160686302996/Baez\&SantosChildrenvulnerability.pdf

Baker, M.L., Sigmon, J.N., \& Nugent, M.E. (2001). Truancy reduction: Keeping students in school. Washington DC: US Department of Njustice, Office of Juvenile Justice Programs, Office of Juvenile Justice and Delingquency Prevention.

Bell, A.J., Rosen, L.A., \& Dynlacht, D. (1994). Truancy intervention. Journal of Research and Development in Education, 27, 203-211.

Berlyne, D. (1960). Conflict, arousal, and curiosity. New York: McGraw-Hill.

Bhalotra, S., \& Heady, C. (2000). Child Farm Labour: Theory and Evidence, STICERD - Development Economics Papers 24, Suntory and Toyota International Centres for Economics and Related Disciplines, LSE.

Boyer,P., Bixler,H., Gordon,H., Heck, A., \& Lee, J.(1939). School Organization and Classroom Adjustment: A. School Attendance. Review of Educational Research , 9 (2), 161-168.

Breuner C, Smith M., \&Womack W. (2004). Factors related to school absenteeism in adolescents with recurrent headache. Headache. Journal Head Face Pain, 44(3), 217-222.

Cain, M. (1977). The economic activities of children in a village in Bangladesh. Population and Development Review, 3(3), pp. 201-227.

Clarke S., Brooker S., Njagi J., Njau E., Estambale B., Muchiri E., \& Magnussen P. (2004). Malaria morbidity among school children living in two areas of contrasting transmission in western Kenya. American Journal of Tropical Medicine and Hygine, 71, 732-738.

Cunningham, M. (1979), Weather, mood, and helping behaviors: Quasi experiments with the sunshine samaritan. Journal of Personality and Social Psychology 37(11), 1947-1956.

Currie, J., Hanushek, E., Kahn, E., Neidell, M., \& Rivkin, S. (2009). Does pollution increase school absences? The Review of Economics and Statistics, 91(4), 682-694.

Duryea, S. (1998). Children's advancement through school in Brazil: The role of transitory shocks to household income. Inter-American Development Bank, Office of the Chief Economist, Working Paper no. 376.

Ellis, A. (1973). Influences on School Attendance in Victorian England. British Journal of Educational Studies, 21(3), 313-326. 
Echterling, L. (1989). An ark of prevention: preventing school absenteeism after a flood. Journal of Primary Prevention, 9, 177-184.

Educar (2010). Ser docentes hoy. Continuidad pedagógica de los aprendizajes con asistencia discontinua. Retrieved March, 15th 2010 from http://portal.educ.ar/debates/eid/docenteshoy/debates/continuidad-pedagogica-de-losaprendizajes-con-asistencia-discontinua.php

Essa, E., Hilton, J. and Murray,C. (1990). The relationship between the weather and preschooler's behaviour. Children's environments quarterly, 7(3), 32-36

Fernando, D., De Silva, D., Carter, R., Mendis, K. \& Wickremasinghe, R. (2006). A randomised, double-blind, placebo-controlled clinical trial of the impact of malaria prevention on the educational attainment of school children. American Journal of Tropical Medicine and Hygine, 74(3), 386-393.

Fowler, R. (1953). Manifestations of Cottonfield Insecticides in the Mississippi Delta. Agricultural and Food Chemistry, 1(6), 469-473.

Freudenberg N., Feldman C., \& Clark N. (1980). The impact of bronchial asthma on school attendance and performance. Journal School Health, 50, 522-526.

Hennecke W. Greve, C., Cowell, P., \& Thom, B., (2004). GIS-Based Coastal Behaviour Modeling and Simulation of Potential Land and Property Loss: Implications of Sea-Level Rise at Collaroy/Narrabeen Beach, Sydney (Australia). Coastal Management, 32(4), 449 - 470.

Hobday, J., \& Stewart, A. (1973). The relationship between daily asthma attendance, weather parameters, spore count and pollen count. Australian and New Zealand Journal of Medicine, 3(6), 552556.

Ilahi, N., Orazem, P., \& Sedlack, G. (2000). The implications of child labor for adult wages, income and poverty: Retrospective evidence from Brazil. International Monetary Fund.

Jacoby, H. \& Skoufias, E. (1997). Risk, Financial Markets, and Human Capital in a Developing Country. The Review of Economic Studies, 64, (3), 311-335.

Kearney, C., \& Bensaheb, A. (2006). School Absenteeism and School Refusal Behaviour: A Review and Suggestions for School-based health professionals. The Journal of School Health, 2006(76), 1 .

Lee, M.I., \& Miltenberger, R.G. (1996). School refusal behaviour: Classification, assessment and treatement issues. Education and Treatment of Children, 19, 474-486.

Lippmann, M. (1989). Health effects of ozone: a critical review. Journal Air Pollution Control Waste Management (United States), 39(5), 672-695.

Lowen A., Mubareka S., Steel J., \& Palese P. (2007) Influenza Virus Transmission Is Dependent on Relative Humidity and Temperature. PLoS Pathogens, 3(10), e151.

Masouleh, F.A.N. (2006). A geographical study of school attendance areas using the multiplicatively weighted Voronoi Method: A case of Rasht City, Iran. (Doctoral dissertation, Graduate School of Life and Environmental Sciences, the University of Tsukuba).

Masterson, E., Borton, D., \& O’Brien, T. (1993). Victims of our climate. Injury, 24 (4), 247-248

McColl S., Veitch J. (2001). Full-spectrum fluorescent lighting: a review of its effects on physiology and health. Psychological Medicine, 31, 949-964.

Moonie, S., Sterling, D. Figgs, L., \& Castro, M. (2006). Asthma Status and Severity Affects Missed School Days. Journal of School Health, 76(1), 18-24.

Orazem, P., \& Gunnarsson, V., (2003). Child labour, school attendance and performance: A review. International Labour Office/ International Programme on the Elimination of Child Labour Working Paper.

Park, H., Lee, B., Ha, E. H., Lee, J. T., Kim, H., \& Hong, Y. C., (2002) Association of air pollution with school absenteeism due to illness. Archives of Pediatrics and Adolescent Medicine, $156,1235-1239$.

Partonen, T., \& Lönnqvist, J.( 1998). Seasonal affective disorder. The Lancet, 352(9137), 1369-1374 
Patz J. Campbell-Lendrum D., Holloway T., \& Foley J. (2005). Impact of regional climate change on human health. Nature, 438, 310-317.

Psacharopoulos, G. (1997). Child labour versus educational attainment: some evidence from Latin America. Journal of Population Economics, 10(4), 377-386.

Queensland Government (2006). Cooler Schools. Retrieved March, $15^{\text {th }} 2010$ from http://education.qld.gov.au/eq/coolerschools/index.html

Ransom M. \& Pope C. (1992). 3rd Elementary school absences and PM10 pollution in Utah Valley. Environmental Research, 58(2), 204-219.

Rosati, F., \& Rossi, M. (2001). Children's working hours, school enrolment and human capital accumulation: Evidence from Pakistan and Nicaragua. Understanding Children's Work. ILO, UNICEF and Worldbank project. Innocenti Research Centre.

Roth-Isigkeit A., Thyen U., Stoven H., Schwarzenberger J., Schmucker P. (2005). Pain among children and adolescents: restrictions in daily living and triggering factors. Pediatrics 115,152-62.

Sedlacek, G., Duryea. S., Ilahi, N., \& Sasaki, M. (2003). Child labour, schooling, and poverty in Latin America, in Orazem et al., Child Labour in Latin America. Social Protection Unit Human Development Network. The World Bank, Washington.

Singh, Kusum. 1998. Part-time employment in high school and its effect on academic achievement. The Journal of Educational Research 91, 131-139.

Srinivasan V., Smits M., Spence W., Lowe A., Kayumov L., Pandi-Perumal S., Parry B., \& Cardinali D. (2006). Melatonin in mood disorders. World Journal of Biological Psychiatry, 7, 138151.

Stokes, I., \& Walton, J. (1999). The effective collection and analysis of attendance data. In Eric Blyth, and Milner, Judith (Eds.), Improving School Attendance, Routledge, London.

Strauss, S., \&Orlove, B. (Eds) (2003). Weather, Climate, Culture. Oxford, New York: Berg Publishers.

Strickland, V. (1998). Attendance and grade point average: A study. (Report No. SP038147. Fast Lansing, MI: National Center for Research on Teacher Learning. (ERIC Document Reproduction Service No. ED423224).

Sullman, F. (1076). Health, weather and climate. Basel ; New York : S. Karger

Swart ,R., Amann, M., Raes, F., \&Tuinstra, W. (2004). A Good Climate for Clean Air: Linkages between Climate Change and Air Pollution. An Editorial Essay. Climatic Change, 66(3), 263-269.

UNESCO (2010). Education for all goals. Retrieved July $15^{\text {th }} 2010$ from http://www.unesco.org/en/efa/efa-goals/

Winkler D., Pjrek E., Iwaki R., \& Kasper S. (2006). Treatment of seasonal affective disorder. Expert Review of Neurotherapeutics, 6, 1039-1048.

\section{About the Authors}

Dr. Olav Titus Muurlink

Dr. Muurlink is a psychologist working as a Research Fellow at the Centre for Work, Organisation and Wellbeing at Griffith University. He is also chairman of the Bangladesh-based Australian charity, Co-operation In Development, which builds primary schools in highlydisadvantaged settings in southern Bangladesh. 
Dr. Cristina Poyatos Matas

Dr. Poyatos Matas is a senior lecturer at Griffith University in the School of Languages and Linguistics. Her research areas include applied linguistics and education. Amongst her interests are education in developing countries, multicultural education, ethnolinguistics, student-centred assessment, research supervision, and academic well-being. 



\section{JOURNAL O GLIMATE CHAMEE}

\section{EDITORS}

Amareswar Galla, The University of Queensland, Australia.

Bill Cope, University of Illinois, Urbana-Champaign, USA.

\section{EDITORIAL ADVISORY BOARD}

Viraal Balsari, Vice President, ABN Amro Bank, Mumbai, India.

Erach Bharucha, Bharati Vidyapeeth Univeristy, Pune, India.

Tapan Chakrabarti, National Environmental Engineering Research Institute, Nagpur, India.

Thomas Krafft, Geomed Research Corporation, Bad Honnef, Germany.

Shamita Kumar, Bharati Vidyapeeth Univeristy, Pune, India.

R. Mehta, Ministry of Environment and Forests, Government of India, New Delhi, India.

Kranti Yardi, Bharati Vidyapeeth Univeristy, Pune, India.

Please visit the Journal website at http://www.Climate-Journal.com for further information about the Journal or to subscribe. 


\section{THE UNIVERSITY PRESS JOURNALS}

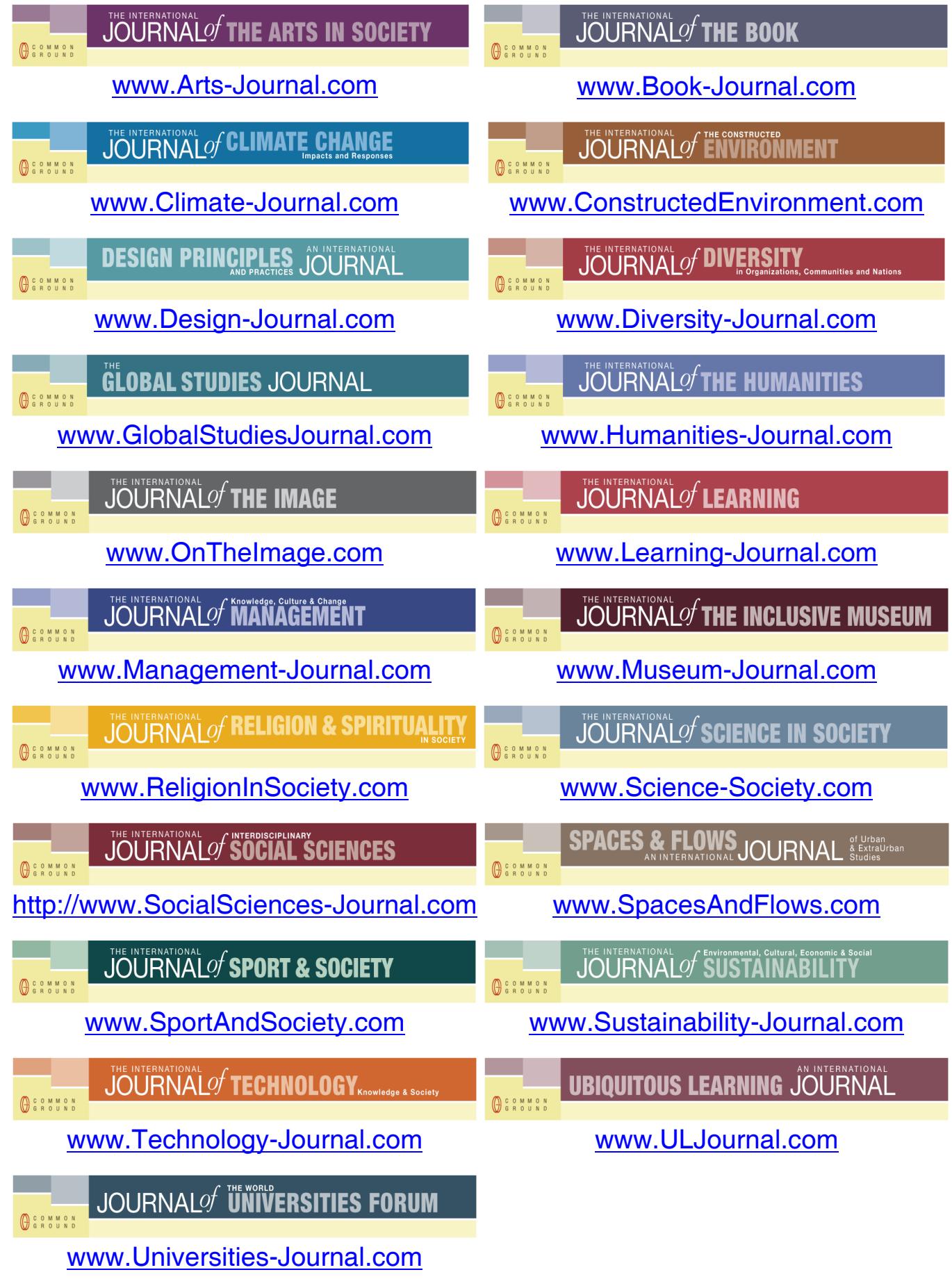

FOR SUBSCRIPTION INFORMATION, PLEASE CONTACT subscriptions@commongroundpublishing.com 